\title{
Revisão Curricular do Secundário pode pôr em Risco Futuro do País
}

A O PROPOR A NĀO OBRIGATORIEDADE DA Física e Química no Ensino Secundário para o prosseguimento de estudos superiores relacionados com as Ciências e ao não incluir nas opções tecnológicas a Química a produtividade do país e a literacia científica dos seus cidadãos pode ser irremediavelmente ameaçada.

Com efeito a revisão curricular do Ensino Secundário discutida recentemente e cuja implementação está prevista para o próximo ano lectivo, além de pecar pela quase total falta de fundamentação, aliás já apontada por entidades de relevo na vida nacional e de quadrantes políticos diferentes como o Prof. Joaquim Azevedo e o Prof. Mariano Gago, apresenta sugestões gravissimas entre as quais a que abre caminho a tornar as áreas de ensino de Química opcionais, mesmo para alunos de áreas científicas e a que propõe a extinção das disciplinas vocacionais e profissionalizantes de Química.

Embora tenha muitos aspectos positivos como a introdução dos novos curricula mais motivantes (pelo menos no que diz respeito à Física e à Química) e necessários para uma possível expansăo da escolaridade obrigatória para os 12 anos, tendência europeia a que este governo já aderiu, a introdução da área curricular não disciplinar de projecto (embora indevidamente concentrada no $12^{\circ}$ ano em vez de estar dispersa pelos três anos) e se compreenda que está possivelmente por trás deste projecto uma corrente emancipatória do ensino secundário que argumenta em favor da desespecialização deste e que foi seguida nos anos 90 em muitos países europeus, esta reforma, a ser concretizada no presente momento, para os dois grandes grupos de alunos que frequentam o Ensino Secundário - os profissionais de química e áreas nela baseadas ou com ela relacionadas e os simples cidadãos conscientes - levaria a um descalabro completo, agravado no primeiro caso pela inevitabilidade do figurino de Bolonha para as Universidades (que em face da redução da duração dos cursos superiores acarreta inevitáveis responsabilidades propedêuticas a nível do Ensino Secundário) e no outro pela aliteracia científica a que conduziria, quando se sabe da enorme importância desta literacia para a tomada de decisões responsáveis no seio da emergente Sociedade de Informaçāo.

Como o currículo é um assunto complexo que tem de ser visto na globalidade, essa globalidade inclui a adopção tão publicitada de uma disciplina independente de Tecnologias de Informação e Comunicação (TIC) que poderá estar na base da pretendida opcionalização de disciplinas tão estruturantes como a Fisica e a Química. A este propósito e com a experiência que me advém de ter coordenado um pólo do Projecto Minerva, de deter a regência da Disciplina de Tecnologia Educativa da Faculdade de Ciências da Universidade do Porto e a coordenação do Mestrado em Educação Multimédia da mesma faculdade, parece-me imperioso afirmar que não faz qualquer sentido no secundário uma disciplina independente de Tecnologias de Informação e Comunicação, quando estas, nesta fase, já têm forçosamente que estar integradas no currículo, pelo menos a aceitar-se como o projecto propõe, as aulas de 90 minutos, pois é uma aberração que se possa pensar que estas possam ser dadas de uma forma convencional, transmissiva. As TIC, nesta fase, deverão ser assumidas duma forma generalizada e transversal e se houver alguma necessidade de as incluir de uma forma descontextualizada no currículo, tal só faria sentido no $1^{\circ}$ e/ou $2^{\circ}$ ciclo do Ensino Básico!

Também a área curricular não disciplinar de Projecto, reconhecidamente pedra angular desta reforma (certamente da iniciada pelo anterior governo e que foi já implementada no Ensino Básico), deve dar continuidade ao que está estipulado nas indicações já vigentes do $3^{\circ}$ ciclo do ensino básico (que passará a $1^{\circ}$ ciclo do novo Ensino Secundário), com um forte pendor científico, reflectindo a nova epistemologia científica (Ciência como Projecto e não como Objecto) e promovendo a integração das várias Ciências e a sua aplicação ao meio envolvente da Escola e de maneira alguma estar concentrada no $12^{\circ}$ ano em que as preocupações dominantes são as de acesso ao Ensino Superior ou de integração na vida activa

Estas reflexões não pretendem limitar-se a uma atitude corporativista e solidária de defender a classe dos professores de Química, que seria gravemente prejudicada (falta de emprego, horários zero,...). Acima de tudo impôe-se o dever nacional de denunciar a enormidade dos erros curriculares propostos envidar todos os esforços no sentido de evitar que eles venham a causar prejuízos irreparáveis para a educação científica das futuras gerações e como tal para a cultura e economia do País... 